\title{
The Efficacy of $\mathrm{KABAT}^{\circledast}$ as a Surface Spray on Oriental Tobacco Bales for Control of the Cigarette Beetle Lasioderma serricorne (F.) (Coleoptera: Anobiidae)*
}

\author{
by D. L. Faustini, R. M. Lehman, J. S. Long and M. A. Manzelli \\ Pbilip Morris Research Center, Richmond, Virginia, U.S.A.
}

\section{SUMMARY}

Methoprene, a synthetic juvenile hormone analogue, was shown to have the capability of preventing the cigarette beetle Lasioderma serricorne ( $\mathrm{F}$.) from propagating when applied to the outside of packaged Oriental tobacco bales. Control was achieved for a 33-month' storage period when methoprene was applied at $40 \mathrm{mg} /$ $\mathrm{m}^{2}$ and $80 \mathrm{mg} / \mathrm{m}^{2}$ to either the burlap sheathing or to the outer surface of the tobacco following removal of the burlap sheath.

\section{ZUSAMMENFASSUNG}

Eine Vermehrung des Tabakkäfers Lasioderma serricorne (F.) in Ballen von Orienttabak läßt sich dadurch unterbinden, daß diese auf der Oberfläche mit Methopren, einem synthetischen juvenilen Hormonanalogon, behandelt werden. Dies konnte über einen Lagerungszeitraum von 33 Monaten nachgewiesen werden, wobei die Ballen mit und ohne Leinenverkleidung von außen mit $40 \mathrm{mg}$ oder $80 \mathrm{mg}$ Methopren je $\mathrm{m}^{2}$ besprüht wurden.

\section{RESUME}

Il est possible de faire cesser la prolifération de la vrillette du tabac Lasioderma serricorne (F.) dans les balles de tabac d'Orient en traitant la surface des balles avec du méthoprène, un analogue d'hormone juvénile synthétique. Ceci a pu être contrôlé pour une durée de stockage de 33 mois en appliquant du méthoprène, à raison de 40 ou $80 \mathrm{mg} \mathrm{par} \mathrm{m}^{2}$, soit sur l'enveloppe de toile, soit sur la surface extérieure du tabac après avoir enlevé la toile.

\footnotetext{
* Received: 5th November 1985 - sccepted: 26th January 1987.
}

\section{INTRODUCTION}

Juvenile hormone analogues have been heralded as the biorational insect control tools of the future. The primary advantages of these compounds are their long residual life, low mammalian toxicity, and their specificity towards target pests. Methoprene, one such juvenile hormone analogue, has been shown to be effective in the control of insects including flies $(1-3)$, mosquitoes $(2,4,5)$, fleas $(6)$, beetles $(7-9)$ and moths $(9,10)$.

$\mathrm{KaBAT}^{\circ}$ (5\% methoprene in alcohol) added to raw tobacco at the $10 \mathrm{ppm}$ level was effective in controlling the cigarette beetle Lasioderma serricorne (F.) while stored in hogsheads (11) and provided protection for a 48-month' storage period (8). Unlike domestic tobacco, Oriental leaf tobacco is packaged in burlap bales prior to storage. The size and weight of the bale are dependent upon the country of origin. The burlap bale design is less costly and easier to handle than the conventional hogshead. Following importation, Oriental tobacco bales are stored for about two years. During the storage period, the tobacco bale warehouse annually receives aerosol insecticide fogging throughout the principal cigarette beetle activity months, as well as a single phosphine fumigation. Treatment of Oriental leaf tobacco with methoprene by the exporter would provide the purchaser with an additional control measure to. assure an insect-free commodity.

In 1982 the Monopolio Italiano Tabacchi (12) reported control of the cigarette beetle by treating only the outer surface of three bales of Oriental tobacco with $\mathrm{KA}$ BAT $^{*}$. Their small-scale study suggested a possible means of controlling the cigarette beetle without treating all the tobacco lamina. Therefore, we report, in a large scale study, the results of spraying methoprene on the: 1. outer surface of baled Oriental tobacco leaf, and 2. burlap jute sheathing that covers the tobacco bale. 


\section{MATERIALS AND METHODS}

\section{Methoprene Dosage and Formulation}

KABAT ${ }^{*}$ contains $5 \%$ technical grade methoprene [isopropyl (2E,4E)-11-methoxy-3,7,11-trimethyl-2,4-dodecadienoate (Zoecon, Palo Alto, Calif.)] in $95 \%$ ethanol. Either $7.05 \mathrm{ml}$ or $14.1 \mathrm{ml}$ of $\mathrm{KABAT}^{*}$ were diluted to $3,000 \mathrm{ml}$ with a mixture of water and ethanol $(75: 25)$ and $500 \mathrm{ml}$ of the solution sprayed on to the leaf surface of the burlap jute surface of each bale to give applications of $40 \mathrm{mg}$ methoprene $/ \mathrm{m}^{2}$ or $80 \mathrm{mg}$ methoprene $/ \mathrm{m}^{2}$, respectively.

\section{Spray Application}

A total of 54 bales of Italian Levantine tobacco was evaluated. All the bales were fumigated under tarpaulin with phosphine at a dosage of $1000 \mathrm{ppm}$ for 96 hours prior to the experiment. This assured that the bales were free of all live stages of the cigarette beetle. Each bale weighed about $19 \mathrm{~kg}$, and its dimensions of 60.9 length $\times 30.4$ width $\times 45.7$ height $\mathrm{cm}^{3}$ gave a total outside surface area of $1.205 \mathrm{~m}^{2}$. The treatments were as follows: 24 bales at $40 \mathrm{mg} / \mathrm{m}^{2}$ methoprene (12 treatments of burlap ${ }^{*} ; 12$ treatments of leaf surface), 24 bales at $80 \mathrm{mg} / \mathrm{m}^{2}$ methoprene (12 treatments of burlap; 12 treatments of leaf surface), and 6 control bales (3 treatments of burlap and 3 treatments of leaf surface with water and ethanol only).

Applications were made using a 4-liter manual pump spray tank. The sprayer, fitted with a fan nozzle, delivered about $9.8 \mathrm{ml} / \mathrm{s}$ at 60 compressions. To expedite bale spraying, 24 bales were positioned on the floor in a single row. The bales were turned to allow coverage of all surfaces. The spray tank was filled with $3,000 \mathrm{ml}$ of water/ethanol/KaBAT (enough to spray 6 bales at one time). The tank was continuously shaken throughout spray application to assure a homogeneous coverage of methoprene. Fans were positioned throughout the area to dry the sprayed bales to prevent mold growth during storage.

\section{Biological and Chemical Assays}

Biological and chemical residue analyses were performed to assess the efficacy of methoprene and the longevity of the residue on the tobacco leaf and burlap jute sheathing.

\section{Biological Assay}

Bioassays were conducted by infesting 6 bales from each treatment group with about 500 cigarette beetle eggs and 500 second-instar larvae on the tobacco surface. Six bales each from the $40 \mathrm{mg} / \mathrm{m}^{2}$ and $80 \mathrm{mg} / \mathrm{m}^{2}$ methoprene groups were "salted" with about 500 eggs

\footnotetext{
* All treatments of burlap were made with the burlap intact around the tobacco bale.
}

and larvae by thieving a core and placing the insects inside. Following the planting of insects the core was returned to plug the hole. The remaining 12 bales, 6 each of $40 \mathrm{mg} / \mathrm{m}^{2}$ and $80 \mathrm{mg} / \mathrm{m}^{2}$ burlap spray treatment, were infested by placing the eggs and larvae on the burlap. Controls were infested in an identical manner.

After the one-time treatment and cigarette beetle infestation, the bales were individually overwrapped with Tyvek", spun-bonded polyethylene film (Dupont, Richmond, $V_{2}$.), to prevent insects from entering or leaving. It should be noted that the burlap sheathing was sewn back on those bales from which it had been removed after the tobacco leaf was treated with methoprene. After the first year of storage, the remaining bales that were not sacrificed for evaluation of insect feeding damage were opened, and a sticky adhesive placard was placed on the top surface of each bale. This was done to monitor any adults that developed by trapping them on the adhesive.

When 18 bales were examined at selected intervals (3, 15 and 33 months) for cigarette beetle adult activity, the $T^{\prime} y^{\prime} v e{ }^{*}$ bag was opened and the bales' outer surface was brushed. This method knocked off any adult forms to the bottom of the Tyvek bag. The resultant material was then collected and sifted on a series of U.S. Standard sieves. The adults were counted and recorded. Following the examination of these bales at each time interval for adult activity, they were destroyed at the conclusion of data collecting. This same procedure was performed for both treatment and control groups.

\section{Chemical Assay}

After the spray had dried, samples of tobacco, to a depth of about $2 \mathrm{~cm}$, were taken for chemical analysis. Samples of treated and untreated tobacco or burlap jute were also taken at irregular intervals during the 33month' storage period for residue analysis. The resultant residue data gave $14 \mathrm{ppm}$ and $28 \mathrm{ppm}$ methoprene, respectively. Methoprene residues were determined by extracting the tobacco leaf and burlap with hexane in the presence of Zoecon's internal standard of ZR-644 (isobutyl ester methoprene analogue) (1). Following further purification the methylene chloride eluate was examined for methoprene residue by gas-liquid chromatography. Single samples of all treated and untreated tobacco or burlap jute were taken at irregular intervals for chemical residue evaluations during the 2-year' storage period.

\section{RESULTS AND DISCUSSION}

The initial application of methoprene directly to the tobacco surface in 1982 appeared to result in reduced adult emergence when compared to spraying burlap jute (Table 1). Although the treatment dosages and methods showed lower values than the controls, the results at first were not encouraging. However, when the 
Table 1.

Methoprene as a surface spray for Orlental bales for the control of the clgarette beetle Lasioderma serricorne (F.). Adults were recorded from the tobacco bale surface and adhesive placards.

\begin{tabular}{l|r|r|r}
\cline { 2 - 4 } & \multicolumn{3}{|c}{$\begin{array}{c}\text { Mean number of } \\
\text { adult cigarette beetles }\end{array}$} \\
\cline { 2 - 4 } & $1982^{*}$ & $1983^{* *}$ & $1984^{* * *}$ \\
\hline 14 ppm methoprene & $108(4)$ & $178(4)$ & $95(4)$ \\
tobacco surface & $334(4)$ & $271(4)$ &, $228(4)$ \\
burlap surface & & & \\
28 ppm methoprene & $40(4)$ & $23(4)$ & $68(4)$ \\
tobacco surface & $145(4)$ & $114(4)$ & $236(4)$ \\
burlap surface & & & \\
control (75:25 - $\left.\mathrm{H}_{2} \mathrm{O} / \mathrm{EtOH}\right)$ & $421(1)$ & $4,500(1)$ & $10,500(1)$ \\
tobacco surface & $376(1)$ & $6,460(1)$ & $11,700(1)$ \\
burlap surface & &
\end{tabular}

All adults recorded from methoprene-treated bales were dead, whereas the control count included live and dead adults.

+ Mean number of replicates Indicated in parentheses.

- 3 months following initial treatment

** 15 months following inittal treatment

*** 33 months following initial treatment

bales were examined at $\mathbf{1 5}$ months after the initial treatment, notable differences were observed. These bales had been seeded with cigarette beetle larvae at the same time as the 3-month' evaluation group. There did not appear to be an increase in cigarette beetle number for either treatment dosage group which was demonstrated by the lack of insects on the sticky placard. This indicated that there was not a propagation of subsequent generations from the initial adult emergence. Examination of the control bales revealed a significant increase in cigarette beetle adults. Furthermore, it should be noted that there did not appear to be a difference between the core or surface insect inoculations.

In 1984, a parallel could be seen in the treatment groups when compared to 1983 results (Table 1). Whether the tobacco surfaces or burlap surface were treated with methoprene, cigarette beetle control was achieved over a 33-month' storage-exposure period. Of particular interest is the observation that mere treatment of the burlap was sufficient to impart control.

Methoprene residue analyses of treated burlap after 33 months showed that $6 \mathrm{ppm}$ and $12 \mathrm{ppm}$ were still present on the burlap surface (Table 2) and $9 \mathrm{ppm}$ on the tobacco directly under the burlap for a depth of about $2 \mathrm{~cm}$. This suggested that the methoprene had translocated into the tobacco. Previous studies have shown that methoprene migration can occur ((13-15) and LeHMAN, unpublished data)). In our laboratory, studies show that cigarette beetle adults and larvae that are exposed to air being swept from methoprenetreated tobacco appear to be affected at the $10 \mathrm{ppm}$ level. BENEZET (13) suggested that prolonged cigarette beetle exposure to sub-lethal methoprene levels affect the synthesis of oöcyte proteins during vitellogenesis resulting in necrosis of the oöcyte.
Table 2.

Methoprene residue analyses from single samples of the final 18 Oriental tobacco bales 33 months following inlital treatment.

\begin{tabular}{c|c|c|c}
\hline No. & $\begin{array}{c}\text { Target } \\
\text { methoprene } \\
\text { concentration } \\
\text { (ppm) }\end{array}$ & $\begin{array}{c}\text { Surface } \\
\text { sprayed }\end{array}$ & $\begin{array}{c}\text { Methoprene } \\
(\mathrm{ppm})^{*}\end{array}$ \\
\hline 1 & 14 & tobacco & 4 \\
2 & 14 & tobacco & 3 \\
3 & 14 & burlap & 1 \\
4 & 14 & tobacco & 0 \\
5 & 28 & burlap & 9 \\
6 & 28 & tobacco & 6 \\
7 & 28 & tobacco & 3 \\
8 & 28 & burlap & 4 \\
9 & 0 (control) & - & 0 \\
\hline 10 & 14 & sample of burlap & 12 \\
11 & 28 & sample of burlap & 6 \\
\hline
\end{tabular}

* Tobacco samples were taken from the outer surface to a depth of $2 \mathrm{~cm}$.

These results suggest that both dosage treatments of $14 \mathrm{ppm}$ and $28 \mathrm{ppm}$ methoprene were efficacious in controlling the cigarette beetle, regardless of whether the burlap or raw tobacco leaf surface was treated. Control was apparently affected by migration and feeding. Those insects initially placed in the bales did not appear to be severely restricted in metamorphosis as in past studies. The low number of adults observed during the three months following treatment evaluation most probably developed from the larvae rather than the eggs used for infestation. Cannibalism is a prevalent factor in autocidal control of the cigarette beetle (16). The first few larvae to eclose consume the remaining eggs (17). The data suggest, however, that those adults in the $F_{1}$ generation were sterile because there was no significant increase in insect population in either of the treatment groups following the $F_{1}$ generation. Adult sterility was demonstrated when Trogoderma glabrum virgin females were held in contact with methoprenetreated absorbent discs (18).

Methoprene apparently migrated from the burlap surface on to the Oriental tobacco and from the bale surface interiorly. This migration may have carried methoprene in sufficient quantities to cause sterilization in eclosing adults. Most of the methoprene concentrations in Table 2 exceed those reported by BENEzET (13) and KLEIN and BURKHOLDER (18) for adult sterility. Even with migration, it is still difficult to explain the degree of cigarette beetle control in those bales where initial insects were placed inside. One can only suggest that a combination of methoprene migration internally coupled with larval or adult migration externally provided an environment where eclosing adults were in contact with sufficient methoprene for a length of time necessary for sterilization.

The benefits derived from this study relate to the fact that while the ability exists in the United States to apply methoprene homogeneously to tobacco it is both 
technologically and economically prohibitive in many countries exporting Oriental tobacco. Since these tobaccos comprise a significant percentage of the final blend, the exterior treatment of burlap, whether by dipping or spraying, would significantly reduce insect control problems for importers while increasing quality of the finished product.

\section{REFERENCES}

1. Miller, R. W., and L. G. Pickens: Evaluation of methoprene formulation for fly control; J. Econ. Entomol. 68 (1975) 810-812.

2. Staal, G. B.: Insect growth regulators with juvenile hormone activity; Annu. Rev. Entomol. 20 (1975) 417-466.

3. Harris, R. L., W. F. Chamberlain and E. D. Frazar: Horn flies and stable flies - Free-choice feeding of methoprene mineral blocks to cattle for control; J. Econ, Entomol. 67 (1974) 384-386.

4. Burgess, N. R. H., and K. N. Chetwyn: Control of the salt marsh mosquito Aedes detritus using growth regulator hormone (Altosid SR 10); Int. Pest Control 25(3) (1983) 74-75.

5. Schaefer, C. H., and W. H. Wilder: Insect developmental inhibitors, 2. Effects on target mosquito species; J. Econ. Entomol. 66 (1973) 913-916.

6. Clark, G. N.: Methoprene - An insect growth regulator for domestic flea control; Chem. Times Trends 5(4) (1982) 52-55.

7. Laschiavo, S. R.: Effects of the synthetic insect growth regulator methoprene and hydroprene on survival, development or reproduction of six stored product insects; J. Econ, Entomol. 69 (1976) 395399.

8. Manzelli, M. A.: Management of stored-tobacco pests, the cigarette beetle (Coleoptera: Anobiidae) and tobacco moth (Lepidoptera: Pyralidae), with methoprene; J. Econ. Entomol. 75 (1982) 721-723.

9. Strong, R. G., and J. Diekman: Comparative effectiveness of fifteen insect growth regulators against several pests of stored products; J. Econ. Entomol. 66 (1973) 1167-1173.

10. Nickle, D. A.: Insect growth regulators - New protectants against the almond moth in stored inshell peanuts; J. Econ. Entomol. 72 (1979) 816819.

11. Lehman, R. M., J. S. Long, M. Williams and M. A. Manzelli: The successful application of KABAT to tobacco for the control of the cigarette beetle $\mathbf{L a}$ sioderma serricome (F.); presented at the 28th Tobacco Workers' Conference, Orlando, Florida, 1979.

12. Modugno, C.: unpublished data.
13. Benezet, H. J., and C. W. Helms: Reproductive potential of cigarette beetle populations exposed to methoprene; Tob. Sci. 29 (1985) 14-15.

14. Staiger, L. E., G. B. Quistad and D. A. Schooley: Stability of $\left[5-{ }^{14} \mathrm{C}\right]$-methoprene on cigarette filler tobacco in glass jars and bright leaf tobacco in simulated hogsheads; J. Econ. Entomol. 76(5) (1983) 999-1001.

15. Frisch, A. F., B. W. Francis, M. K. Chavis and R. W. Jenkins: Cigarette smoke formation studies, VII. The fate of $\left(5-{ }^{14} \mathrm{C}\right)$-methoprene in cigarette smoke; Beitr. Tabakforsch. Int. 11 (1982) 203208.

16. Howe, R. W.: Laboratory study of the cigarette beetle Lasioderma serricome (F.) (Col, Anobiidae) with a critical review of the literature on its biology; Bull. Entomol. Res. 48(1) (1957) 9-56.

17. Lefkovitch, L. P., and J. E. Currie: The effects of food storage upon larvae of Lasioderma serricome (F.) (Coleoptera, Anobiidae); Bull: Entomol. Res. 54 (1963) 535-547.

18. Klein, J. A., and W. E. Burkholder: Effects of Dianex (methoprene) on growth and reproduction of Trogoderma glabrum (HERBsT) (Coleoptera: Dermestidae); J. Environ. Entomol. 13(5) (1984) 1340-1345.

\section{Acknowledgments}

We thank the Pbilip Morris Leaf Department for its cooperation in permitting use of warebouse space for this study. We also thank Mr. Robert Cunningham for assisting us with the initial methoprene applications, and a very special thank-you to Mr. Jeff Sampson of Universal Leaf Tobacco (Richmond Va.) for conducting the metboprene residue analyses.

Authors' address:

Philip Morris Research Center,

P.O. Box 26583,

Ricbmond, Virginia, 23261, U.S.A. 